\title{
PEMAHAMAN TEORITIK TENTANG ANALISIS KUANTITATIF DALAM GEOGRAFI KERUANGAN DAN PEMANFAATANNYA BAGI TELAAH ARKEOLOGI*
}

Oleh: Bugie MH Kusumohartono

Pada hakekatnya geografi adalah disiplin yang mengkaji gejala gejala fisis dan kultural, segala aspek bumi seperti permukaan beserta segala kehidupan makhluk di atas bumi (Hagget, 1972:451). Termi. nologi inı merupakan salah satu di antara sekian banyak batasan yang dipandang cukup bersesuaian bagi telaah kebudayaan, termasuk di antaranya yaitu disiplin arkeologi

Mengingat arkeologi berfokuskan pada studi kebudayaan (Binford. 1962. Thomas. 1974). maka dengan sendirinya bertalian erat dengan tiga wujud dalam sistem kebudayaan. Ketiga wujud tersebut adalah wujud sistem nilai, wujud sistem perilaku, dan wujud kebudayaan materi (Koentjaraningrat. 1979). Ketidaksejajaran waktu dengan sasaran studinya mengakibatkan arkeologi hanya dapat ber. tatapan dengan wujud kebudayaan materi masa lampau. Perolehan tersebut sepenuhnya diarahkan untuk dapat memahami wujud sistem nilai dan sistem perilaku dari kurun waktu yang bersangkutan.

Dengan demikian wujud kebudayaan materi adalah subyek studi arkeologi. Lebih lanjut Spaulding (1960:439) menegaskan bahwa subyek dari studi arkeologi tersebut adalah artefak, pengertian yang mengacu pada berbagai ragam benda sebagai produk kegiatan budaya manusia.

Suatu deposit maupun himpunan artefak secara relatif berkait erat dengan keberadaannya pada suatu bentang fisis dan gejala lingkungan tertentu. Hal ini merupakan titik tolak yang menyebabkan kerap kali geografi dan arkeologi memiliki minat ilmiah yang kurang

- Dedikası unluk mengenang almarhum Bapak Prof. Drs. Surastopo Hadisumarne. 
lebih sama (Hodder and Orton, 1976:54). Sejauh ini manfaat disiplin geografi dalam arkeologi Indonesia telah dirasakan terutama melalui penerapan dua buah teknik atau pendekatan, yaitu geomorfologi dan penginderaan jauh (Surastopo, 1985). Pendekatan geomorfologi bagi arkeologi di Indonesia telah mampu untuk digunakan bagi kegiatan penelitian, seperti misalnya merekonstruksi keruntuhan bangunan atau pemukiman (Sampurno dan Bandono, 1980; Budianto, 1983) maupun untuk mengkaji latar belakang pembangunan suatu fasilitas tertentu (Bugie, 1986). Sedang pendekatan penginderaan jauh (remote sensing) bagi arkeologi di Indonesia terutama dimanfaatkan bagi kegiatan survei maupun yang bertujuan merekonstruksi bentuk dan struktur suatu situs (Maulana, 1983; Surastopo and Sutikno, 1985; Surastopo and Widya Nayati, 1985).

Berkait dengan kesepakatan bahwa artefak memiliki hubungan yang intens dengan keberadaannya pada suatu bentang fisik dan gejala lingkungan tertentu maka sebenarnya lebih luas lagi cakupan pendekatan geografi yang dapat dimanfaatkan dalam berbagai telaah arkeologi. Selain pendekatan kualitatif, sebagaimana berlaku pada teknik geomorfologi dan penginderaan jauh, maka dapat pula diterapkan pendekatan kuantitatif sebagaimana berlaku pada geografi keruangan.

II

Perkembangan disiplin geografi mutakhir melahirkan hasil berupa bentuk yang disebut sebagai geografi terpadu (integrated geography). Sintesa geografi modern ini tidak membedakan elemen fisis dan non fisis dalam hampirannya. Hampiran (approach) utama dalam geografi terpadu meliputi analisis keruangan (spatial analysis), analisis ekologi (ecology' analysis), dan analisis kompleks wilayah (regional complex analysis) (Haggett, 1972:453).

Analisis secara umum dalam geografi keruangan mempelajari perbedaan lokasi mengenai sifat-sifat penting atau seri sifat-sifat penting. Dengan analisis keruangan diupayakan untuk mengungkap faktor-faktor yang mempengaruhi atau menentukan pola penyebaran dan menentukan cara untuk mengubah pola tersebut agar penyebarannya menjadi lebih efisien. Dengan demikian maka analisis keruangan harus memperhatikan penyebaran penggunaan ruang 
yang ada dan juga penyediaan ruang yang akan digunakan untuk berbagai manfaat sebagaimana direncanakan (Bintarto dan Surastopo, 1982:12-13).

Hampiran keruangan dalam geografi terutama bermanfaat bagi kegunaan perencanaan. Dengan kata lain, hasil-hasil penyebaran aktivitas manusia di muka bumi dapat dianalisis melalui hampiran ini. Dalam perencanaan, penyebaran dapat dirancang melalui proses analisis tertentu. Sebaliknya, suatu hasil penyebaran dapat dianalisis untuk mengetahui determinan yang digunakan dalam perancangan hasil tersebut.

Hampiran yang berlangsung dalam geografi keruangan ini sedikit banyak bersesuaian dengan situasi data arkeologi. Pada umumnya berbagai jenis data dan subyek arkeologi dijumpai dalam jumlah yang relatif besar dan berada dalam lokasi yang juga relatif luas. Berbagai jenis situs, baik yang berupa area hunian, area sumber daya, area upacara, area penguburan, area perbengkelan, dan jenis-jenis area aktivitas yang lain berasosiasi dengan kebutuhan akan pemanfaatan kerangka analisis keruangan (Clarke, 1977:1-5).

Penyebaran situs hunian dalam area tertentu pada jaman prasejarah di Indonesia dapat diperoleh contohnya di situs Gunung Wingko, Yogyakarta (Goenadi, 1974; 1975; Soejono, 1984:281); situs budaya Sampung, Ponorogo (Daud, 1985); dan situs Bukit Kerang (shell kitchenmidden), Sumatra timur laut (Heekern, 1972:85-92). Pada jaman Indonesia kuna terdapat data penyebaran kota-kota kuna, sebagaimana terungkapkan melalui sumber tertuliș. Upaya mengidentifikasikan lokasi kota-kota kuna tersebut telah dilakukan oleh Hasan Djafar (1978: Peta I dan II). Konstelasi kota-kota kuna tersebut berada di kawasan Jawa bagian tengah dan timur dari rentang waktu abad XIV dan XV M. Penyebaran situs hunian dari tahap awal perkembangan urbanisasi telah pula berhasil dijumpai di Thailand. Memperhatikan pola penyebaran situs-situs hunian di Thailand tersebut maka dapat diidentifikasikan bahwa pola penyebaran yang diterapkan adalah primate (Miksic, 1986:14).

Penyebaran hasil aktivitas manusia pada sebuah area sumber daya alam (catchment area) belum begitu banyak diungkapkan dalam studi arkeologi Indonesia. Kajian ini berkemampuan untuk mengungkapkan pola exploitasi sumber daya alam pada area tertentu oleh 
komunitas tertentu. sebagaimana telah diteliti di Palestina khususnya dan berbagai kawasan lain (Clarke, 1977:16-22: Foley, 1977: 163 - 185; Hodder and Orton. 1976:231-6). Contoh studi arkeologi tentang penyebaran hasil budaya manusia dalam suatu area sumber daya alam di Indonesia sedikit banyak telah disinggung oleh N.C. van Setten van der Meer. Dalam telaahnya, Meer meninjau perilaku ekonomis (economic behavior), secara khusus pada penyebaran perangkat keairan berupa waduk kuna di Jawa Timur. Perangkat rekayasa keairan tersebut tersebar di sepanjang benteng lahan-lahan pertanian di dataran tepi Sungai Brantas (Meer, 1979: 9, 20, 134, 136).

Adalah hal yang kerap kali pula dijumpai di Indonesia bahwa pada sebuah areal yang luas terdapat sebaran fasilitas keagamaan dalam intensitas yang tinggi. Sebagai contoh, misalnya sebaran kelompok-kelompok fasilitas pemujaan megalitik situs Pojok Tilu, Brebes (Harry Widianto, 1985), dari periode prasejarah. Pada jaman Indonesia kuna, pengungkapan tentang sebaran fasilitas keagamaan dalam areal tertentu telah banyak dikemukakan. Beberapa di antaranya adalah: situs Gedong Songo dan Dieng (Krom, I, 1923); situs Muara Jambi (Mundardjito, 1984); situs Gumuk Klinting, Banyuwangi (Issatriadi, 1977); situs Candi Deres (Gumuk Candi), Jember (Selarti dan Bugie, 1986); situs Penanggungan (Romondt, 1951); dan masih beberapa yang lain.

Penyebaran hasil budaya manusia berupa kubur pun cukup anyak diungkapkan dalam studi arkeologi Indonesia. Sebaran situs kubur tradisi Megalitik terdapat pada area yang cukup luas di kawasan Gunung Kidul, Yogyakarta (Haris, 1971). Sebaran situs kubur dari beberapa kurun masa terdapat cukup padat di Pulau Selayar, Sulawesi Selatan (Sonny, 1984).

Sedang sebaran situs perbengkelan pada suatu area tertentu yang luas terutama dijumpai pada periode bercocok tanam di Indonesia. Truman Simanjuntak telah melakukan penelitian dan menerbitkan beberapa situs perbengkelan di kabupaten Purbalingga, Jawa Tengah, yang meliputi situs Limbasari-Ponjen-Kertanegara. Di luar itu masih terdapat potensi sebaran situs perbengkelan di wilayah ini yang belum semuanya dapat terjangkau kegiatan penelitian (Simanjuntak dan Harry, 1986). 
Perian di atas hanya mengemukakan sebagian kecil saja dari sekian banyak komplex situs, dari berbagai jenis dan karakter situs. Contoh-contoh di atas juga dengan jelas memperlihatkan penyebaran penggunaan ruang oleh tinggalan-tinggalan arkeologis dari suatu komunitas tertentu. Berkaitan dengan itu selalu timbul pertanyaan faktor-faktor apakah yang mempengaruhi dan menentukan perancangan penyebaran tersebut. Bagi masalah dengan latar belakang seperti di atas, geografi keruangan menyiapkan 'tool of analysis'nya. Paling tidak tersedia kerangka rujukan untuk menghampiri masalah terssbut.

\section{III}

Hampiran keruangan berpotensi untuk menganalisis determinan yang melandasi penyebaran hasil budaya pada suatu area tertentu. Analisis keruangan merupakan analisis lokasi (locational analysis) yang memfokuskan pada tiga unsur utama geografi, yaitu jarak (distance), kaitan atau saling pengāruh (interaction), dan gerakann (movement). Dari ketiga unsur utama yang terungkapkan tersebut dapat pula digambarkan jaringan (network) yang terbentuk di antara anggota sebaran, maupun keterhubungan (connectivity) yang berlangsung di dalamnya.

\section{Model dan Analisis Tetangga-Terdekat}

Dalam studi mengenai pola pemukiman (settlemeni pattern) dalam arkeologi kerap kali dibutuhkan kesimpulan yang terukur untuk menentukan rancang bangun pola yang diterapkan. Melalui metoda kuantitatif, pola suatu sebaran situs hunian, dan bahkan berbagai jenis sebaran situs yang lain (Hodder and Orton, 1976: 17), dapat dinilai bentuknya yaitu seragam (uniform/regular), acak (random) atau mengelompok (clustered) (Haggett, 1970: 89; Hodder and Orton, 1976: 41). Pemanfaatan metoda kuantitatif dalam penentuan pola suatu sebaran dikenal sebagai analisis tetangga-terdekat (nearestneighbour analysis) (Bintaro dan Surastopo, 1982: 74; Hivernel and Hodder, 1984: 100 - 7, Hodder, 1977: 228).

Analisis tetangga-terdekat pada umumnya dilakukan pada situasi ketika kepadatan sebaran relatif tinggi dan peta areal penelitian sebaran relatif luas (Hivernel and Hodder, 1984: 97). Oleh karena itu 
dalam penerapan model analisis ini harus dilalui prosedur sebagai berikut: $a$. Tentukan batas wilayah penelitian sebaran, $b$. Ubah pola sebaran tinggalan arkeologis menjadi penyebaran titik, c. Ukur jarak lurus terdekat, antara satu titik dengan titik lain yang merupakan tetangga terdekatnya. Langkah analisis berikutnya adalah menghitung besar parameter tetangga terdekat (nearest-neighbour statistic) $T$ dengan rumus:

$$
\begin{aligned}
& T=\frac{\overline{\mathrm{j}}_{\mathrm{u}}}{\overline{\mathrm{j}}_{\mathrm{h}}} \\
& \mathrm{T}=\text { indeks atau parameter tetangga-terdekat } \\
& \overline{\mathrm{j}}_{\mathrm{u}}=\text { jarak rata-rata yang diukur antara satu titik dengan } \\
& =\frac{\Sigma j}{\Sigma} \mathbf{N}=\frac{\text { jumlah jarak terdekat untuk semua titik }}{\text { jumlah titik }} \\
& \overline{\mathrm{j}}_{\mathrm{h}}=\text { jarak rata-rata yang diperoleh andaikata sebaran titik } \\
& =\frac{1}{2 \mathrm{~V} p}=\frac{1}{2 \mathrm{~V} \frac{\Sigma \mathrm{N}}{\mathrm{L}}}=\frac{1}{2 \mathrm{~V} \frac{\text { jumlah titik }}{\text { luas areal sebaran }}}
\end{aligned}
$$

Parameter tetangga-terdekat sebagai hasil penghitungan rumus tersebut merupakan nilai yang mencerminkan pola yang diterapkan pada sebaran yang bersangkutan. Apabila $T=1,0$ berarti menerapkan pola acak. $\mathrm{T}=0$ berarti menerapkan pola mengelompok. Sedang $T=2,15$ berarti menerapkan pola seragam. Ketiga index di atas merupakan nilai ekstrim bagi masing-masing jenis pola. Untuk mempermudah perbandingan antara beberapa pola sebaran, maka parameter tetangga-terdekat $\mathrm{T}$ dapat digambarkan sebagai suatu continuum (Bintarto dan Surastopo, 1982: $75-7$ ):

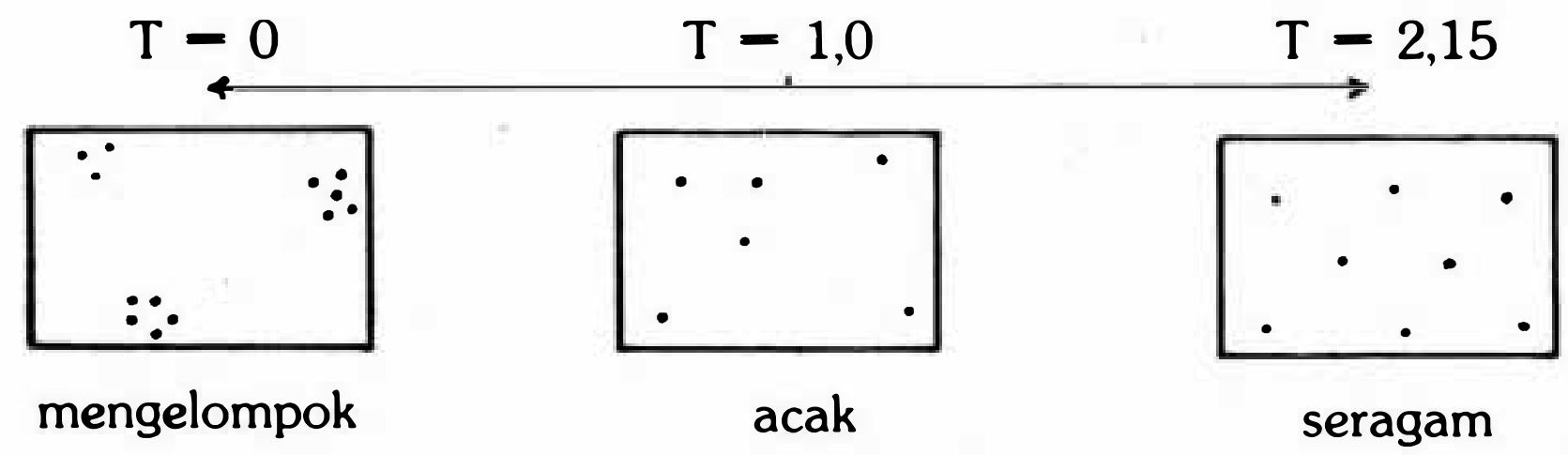


Pemanfaatan model analisis tetangga-terdekat tidak berlaku universal untuk semua situasi areal penelitian. Analisis tetangga-terdekat dapat diterapkan terutama untuk daerah yang tidak memiliki hambatan-hambatan alamiah yang sulit teratasi. Model analisis ini pada umumnya memperhatikan areal sebaran sedemikian rupa sehingga berbagai titik-titik di dalamnya dapat saling berhubungan.

\section{Jarak dan Salingpengaruh (interaction) dalam Ruang}

Sejak pertengahan abad yang lalu, para ahli interaksi sosial, demografi, dan geografi telah merumuskan bahwa gerakan (movement) dalam migrasi adalah berbanding lurus dengan jumlah jiwa yang mengadakan migrasi dan berbanding terbalik dengan jarak yang memisahkannya. Perbincangan tentang kaitan antara jarak dengan jumlah orang yang beremigrasi telah dikembangkan dan dijelaskan sedemikian canggih dengan menggunakan rumus-rumus matematika (Bintarto dan Surastopo, 1982: 79-80).

\section{A. Model Gravitasi dan Salingpengaruh dalam Ruang}

Gerakan di antara beberapa titik dalam ruang pada hakekatnya memperlihatkan suatu operasionalisasi gaya tarik menarik (gravity) di antara masing-masing titik tersebut. Menurut hukum gravitasi yang dikemukakan oleh Sir Isaac Newton, dua benda akan saling tarik menarik dengan gaya yang besarnya berbanding lurus dengan perkalian massa kedua benda tersebut dan berbanding terbalik dengan jarak pangkat dua.

Model gravitasi dan salingpengaruh dalam ruang diterapkan dengan prosedur yang hampir serupa dengan analisis tetangga-terdekat: a. Tentukan luas wilayah sebaran, b. Ubah pola sebaran tinggalan arkeologis (artefak, situs) menjadi penyebaran titik, c. Ukur jarak tersingkat dari jalan yang menghubungkan masing-masing titik dalam ruang. Langkah analisis berikutnya adalah menghitung besaran interaksi antar dua titik dengan suatu model gravitasi:

I12 = saling pengaruh antara titik 1 dan 2

P1 = jumlah penduduk titik 1

P2 = jumlah penduduk titik 2

$\mathrm{J} 12=$ jarak antara titik 1 dan 2 
a = suatu konstante empirik (pada model gravitasi, dianggap 1).

b = suatu eksponen jarak (pada model gravitasi, dianggap 2).

(Bintarto dan Surastopo, 1982: 80; Hodder, 1972: 330).

Dalam penerapan rumus di atas, perkalian jumlah penduduk antara dua titik (P1 P2) dapat disederhanakan angkanya sehingga hasil yang diperoleh lebih sederhana pula angkanya walaupun tidak berkurang keakuratannya. Selain itu perlu pula diperhatikan bahwa interaksi ini diterapkan dengan asumsi bahwa kondisi prasarana perhubungan yang menghubungkan masing-masing titik tersebut sama.

Seandainya model gravitasi ini dapat diterapkan pada suatu area penyebaran situs urban dari jaman Indonesia kuna, kemungkinan gambaran salingpengaruh dan mobilitas yang berlangsung adalah sebagai berikut:

$$
\begin{aligned}
& \text { I } M P=5,1 \\
& \text { I } P G=2,9 \\
& \text { I } \mathrm{JW}=3,5 \\
& \text { I } \mathrm{MW}=1,3
\end{aligned}
$$

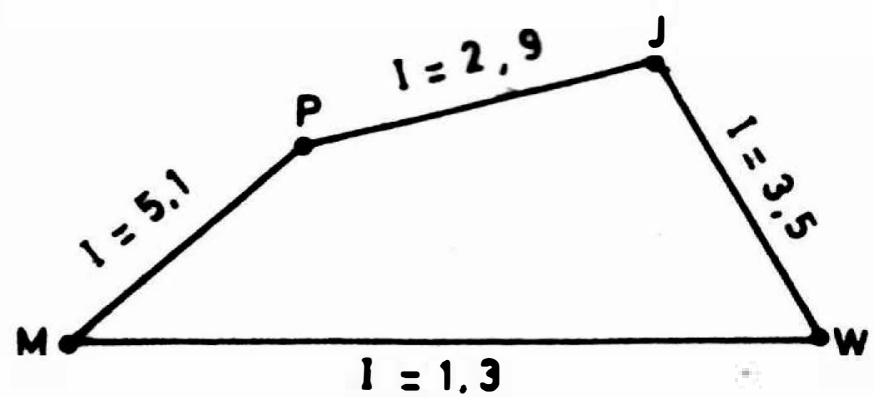

$\mathrm{M}=$ Mataram

$P=$ Pajang

$\mathrm{J}=$ Jagaraga

$\mathrm{W}=$ Wengker.

Pemetikan data jarak antara dua titik bagi model analisis ini nampaknya tidak terlalu sulit bagi telaah arkeologi. Kesulitan yang dialami adalah pada penyediaan data berupa populasi penduduk dalam satu wilayah tertentu, yang biasanya menjadi obyek kajian arkeologi kependudukan (demographic archaeology). Estimasi jumlah penduduk pada situs-situs arkeologi telah banyak diungkapkan di luar Indonesia, terutama melalui perhitungan jumlah tinggalan rangka manusia, jumlah tinggalan arkeologis tetentu (gerabah, alat rumah tangga, rumah, dan lain sebagainya), dan daya dukung lingkungan dalam suatu relung ekologi tertentu (Hassan, 1981). Prasasti memberikan pula data mengenai populasi penduduk, sebagaimana telah diteliti oleh MM Sukarto Kartoatmodjo di Bali (Bambang, 1984: 346 - 8). Yang pasti, penerapan model gravitasi guna memperoleh gambaran tentang salingpengaruh dan mobilitas dalam ruang masih menunggu hasil-hasil penelitian lebih lanjut pada bidang arkeologi kependudukan di Indonesia. 


\section{B. Model Gravitasi dan Potensi Penduduk}

Dengan formula sebagaimana berlaku pada sub-bab atas, model gravitasi dapat digunakan untuk mengetahui potensi penduduk di suatu lokasi tertentu. Nilai potensi penduduk (PP1, PP2, PP3, ...PPn) menunjukkan potensi aliran (flow potensial) untuk suatu area tertentu.

Sebagai misal terdapat himpunan tempat $(1,2,3, \ldots \mathrm{n})$ yang masing-masing mempunyai populasi penduduk ( $\mathrm{P} 1, \mathrm{P} 2, \mathrm{P} 3, \ldots \mathrm{Pn})$, maka potensi penduduk (PP) untuk tempat 1 adalah sebagai berikut:

$$
\mathrm{PP}_{1}=\mathrm{a} \frac{\mathrm{P}_{1}}{\left(1 / 2 \mathrm{~J}_{1}\right)^{\mathrm{b}}}+\mathrm{a} \frac{\mathrm{P}_{2}}{\mathrm{~J}_{12} \mathrm{~b}}+\mathrm{a} \frac{\mathrm{P}_{3}}{\mathrm{~J}_{13}{ }^{\mathrm{b}}}+\ldots+\mathrm{a} \frac{\mathrm{P}_{\mathrm{n}}}{\mathrm{J}_{1 \mathrm{n}} \mathrm{b}}
$$

Sedang potensi penduduk (PP) tempat 2 adalah sebagai berikut:

$$
\mathrm{PP}_{2}=\mathrm{a} \frac{\mathrm{P}_{2}}{\left(1 / 2 \mathrm{~J}_{2}\right)^{\mathrm{b}}}+\mathrm{a} \frac{\mathrm{P}_{1}}{\mathrm{~J}_{21} \mathrm{~b}}+\mathrm{a} \frac{\mathrm{P}_{3}}{\mathrm{~J}_{23} \mathrm{~b}}+\ldots+\mathrm{a} \frac{\mathrm{P}_{\mathrm{n}}}{\mathrm{J}_{2 \mathrm{n}} \mathrm{b}}
$$

dan demikian seterusnya hingga PPn.

PP1 = potensi penduduk di tempat 1 .

$\mathrm{J} 12 / \mathrm{J} 1 \mathrm{n}=$ jarak antara tempat 1 dengan tempat 2 atau tempat $\mathrm{n}$.

J1./J2. = jarak antara tempat 1 atau tempat 2 dengan tempat yang terdekat dengan 1 atau 2.

$\mathrm{P} 1 / \mathrm{Pn}=$ jumlah penduduk di tempat 1 atau di tempat $\mathrm{n}$.

$\mathrm{a}=$ konstante empirik (pada model gravitasi dianggap 1).

$\mathrm{b}=$ eksponen jarak (pada model gravitasi dianggap 2).

(Bintarto dan Surastopo, 1982: 82-5).

Gambaran tentang potensi aliran atau nilai potensi penduduk pada suatu area tertentu dapat ditunjukkan dalam suatu peta potensi. Potensi penduduk pada suatu area dilukiskan dengan garis kontur yang menghubungkan tempat-tempat berpotensi penduduk sama atau isopleths (equi-potential lines). Index angka untuk titik-titik yang menjadi garis kontur merupakan hasil prosentase nilai potensi penduduk masing-masing tempat terhadap tempat dengan nilai potensi 
penduduk tertinggi. Dari berbagai penelitian dalam telaah geogafi keruangan, prosentase tinggi dari potensi penduduk suatu tempat pada umumnya berkaitan dengan populasi penduduknya yang relatif tinggi, sumber daya alamnya yang relatif baik, fasilitas umumnya yang relatif memadai, hubungan dengan luar yang relatif mudah, dan lain sebagainya.

\section{Jaringan}

Pendekatan keruangan dalam disiplin geografi sangat memperhatikan analisis jaringan (network). Jaringan adalah suatu sistem garis yang bertalian erat dengan aspek perhubungan dan pengangkutan serta selalu melalui jalur-jalur tertentu (jalan raya, alur pelayaran sungai, lintasan perhubungan udara, dan lain sebagainya). Berlandaskan pada teori graf, struktur suatu jaringan secara topologis dapat dirinci atas tiga unsur utama yaitu titik (nodes), mata rantai (links), dan wilayah (regions) atau jaringan terisolasi (sub-graphs). Selain ituterdapat elemen lain yaitu panjang tiap mata rantai pada suatu route (Bintarto dan Surastopo, 1982: 86-93).

Jaringan yang terbentuk dari adanya titik (situs) dan garis (transportasi dan komunikasi) berkembang dari tingkat yang sederhana pada awalnya ke tingkat yang lengkap dan canggih pada kurun waktu yang kemudian. Perkembangan suatu jaringan berkaitan erat dengan perkembangan dan pertumbuhan kawasan yang bersangkutan, terutama dalam bidang sosioekonomi dalam arti yang luas. Perkembangan jaringan dari satu tahap ke tahap yang lebih lanjut diperlihatkan oleh angka-angka index tertentu pada tiga aspek utama jaringan, yaitu keterhubungan (connectivity), bentuk jaringan (shape of network), dan keterpusatan (centrality) (Miksic, 1984: 14-9).

\section{A. Jaringan dan Keterhubungan}

Yang dimaksud dengan keterhubungan di sini adalah derajat kepadatan jalur komunikasi dan/atau transportasi pada suatu daerah tertentu (Miksic, 1984: 16). Ada beberapa cara atau index yang dapat digunakan untuk menunjukkan keterhubungan suatu graf, misalnya index angka siklomatik (cyclomatic number), index Alpha (Alpha index): baik untuk graf planar maupun non-planar, dan yang paling sederhana adalah index Bheta (Bheta index) (Bintarto dan Surastopo, 1982: 89-94). 
Index Bheta dipandang sederhana dalam penggunaannya karena dalam formulasinya hanya dibutuhkan data berupa jumlah titik (t) dan jumlah mata rantai $(\mathrm{m})$. Kedua jenis data ini relatif mudah pemetikan atau pengadaannya dalam telaah arkeologi. Besaran suatu index bheta dinyatakan dengan formula:

$$
\text { Bheta }=\frac{\mathrm{m}}{\mathrm{t}}
$$

Nilai index Bheta akan berkisar pada julat (range) dari nol hingga tiga.

Pada suatu jaringan dengan jumlah titik tetap, penambahan mata rantai akan meningkatkan pula nilai index Bhetanya. Nilai indeks Bheta kurang dari satu akan ditampilkan sebagai bentuk graf pohon (tree graph) atau pola dendritik. Menurut Miksic (1984: 16), graf atau pola ini selaras dengan ungkapan bentang tanah administratif, di mana struktur politik dan konstelasi hunian bersifat relatif lebih sentralistis. Dalam graf ini, sebuah titik hanya memiliki satu jalur transportasi dan komunikasi saja. Sebaliknya nilai index Bheta $\geqslant$ satu berarti setiap titik memiliki dua alternatif atau lebih bagi jalur transportasi serta komunikasinya. Di bawah ini diperlihatkan suatu perbandingan antara derajat keterhubungan pada beberapa sistem jaringan dengan menggunakan index Bheta:

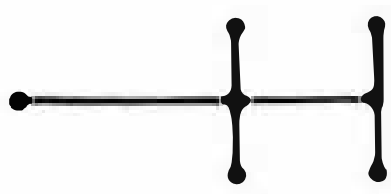

Bheta $=0.86$

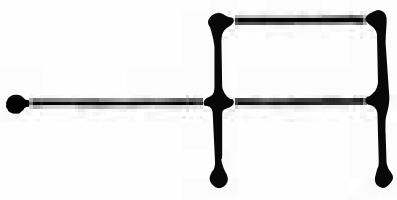

Bheto $=1.00$

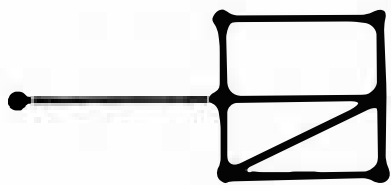

Bheta $=1,29$

Dalam penganalisisan wilayah dan menunjukkan pertumbuhan kebudayaan tinggi di Sumatra Selatan, Miksic (1984: 18) menggunakan index Bheta guna menggambarkan derajad keterhubungan pusatpusat hunian di wilayah itu sejak abad VII M. Besaran index Bheta yang berhasil diestimasikan pada jaringan perhubungan darat dan air di wilayah itu sekurang-kurangnya adalah 1,25 . Setiap besaran di atas satu merupakan petunjuk bahwa jaringan yang bersangkutan bersifat majemuk atau kompleks. 


\section{B. Bentuk Jaringan}

Sebagaimana kegunaan index keterhubungan, yaitu untuk mengetahui derajat perkembangan suatu jaringan, maka pemahaman tentang bentuk jaringan (shape of network) bermanfaat pula untuk kepentingan yang kurang lebih serupa. Semakin besar index bentuk suatu jaringan berarti semakin canggih perkembangan sosioekonomi masyarakatnya. Indeks bentuk jaringan kereta api negara maju seperti Perancis adalah 30 , sedangkan untuk negara berkembang seperti Bolivia adalah lebih kurang satu (Bintarto dan Surastopo, 1982: 97; Miksic, 1983: 18).

Pengukuran index bentuk suatu jaringan membutuhkan datadata berupa diameter jaringan (Ø), jumlah panjang seluruh mata rantai dalam jaringan $(\mathrm{J})$, dan jumlah rata-rata panjang seluruh mata rantai dalam diameter jaringan (j). Diameter jaringan adalah index untuk mengukur panjang suatu graf, dengan cara menjumlahkan mata rantai pada route langsung yang menghubungkan titik-titik atau tempat-tempat terjauh. Sedangkan index bentuk jaringan diperoleh dengan perierapan formula:

$$
\pi=\mathrm{J} / \mathrm{j}
$$

(Bintarto dan Surastopo, 1982: 95-6).

Di bawah ini disajikan dua buah jaringan hipotesis dan cara pengukuran diameter maupun bentuk jaringan. Pada jaringan $A$. titik-titik terjauh dapat dicapai dengan route terdekat melalui dua buah mata rantai. Dengan demikian maka diameter jaringan A adalah 2. Sedangkan dengan teknik yang sama dapat dihitung bahwa diameter jaringan $B$ adalah 4 . J pada jaringan $B$ diperoleh dengan cara menjumlahkan panjang mata rantai-mata rantai: $12+26+67+79+$ $34+45+24+46+78=\mathrm{J}$. Kemudian j pada jaringan $B$ diperoleh dengan cara-cara:

$$
j=\frac{(u+V 5 w+x+y+z)}{p}
$$

apabila $\mathrm{u}=$ panjang diameter jaringan yang menghubungkan titik $1-8$, melalui titik 2, 6, 7 . 
$v=$ panjang diameter jaringan yang menghubungkan titik $1-9$, melalui titik 2,6, 7 .

$w=$ panjang diameter jaringan yang menghubungkan titik $3-8$, melalui titik 4, 6, 7 .

$\mathrm{x}=$ panjang diameter jaringan yang menghubungkan titik 3 - 9. melalui titik 4, 6, 7 .

$y=$ panjang diameter jaringan yang menghubungkan titik 5 - 8, melalui titik 4, 6, 7 .

$\mathrm{z}=$ panjang diameter jaringan yang menghubungkan titik $5-9$, melalui titik 4, 6, 7 .

$\mathrm{p}=$ konstante pembagi untuk memperoleh hasil ratarata jumlah panjang diameter jaringan.

A

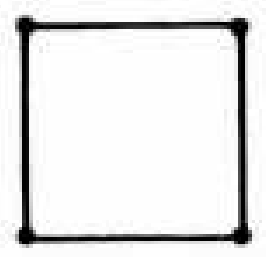

B

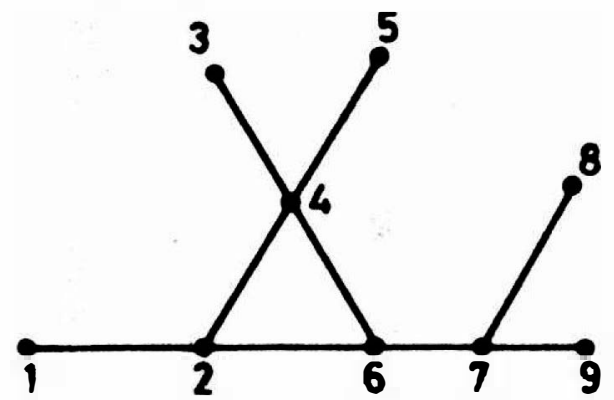

(Bintarto dan Surastopo, 1982: 95-6 dengan beberapa penyederhanaan).

Pengukuran bentuk jaringan dalam analisis wilayah telah pula diterapkan oleh Miksic (1984: 18 - 9) di Sumatra Selatan. Berdasarkan penghitungan terhadap panjang jarak seluruh mata rantai perhubungan darat dan air (sungai) di kawasan itu diperoleh J sebesar 1.260. Sedangkan diameter jaringan tersebut adalah 7 . Kemudian penghitungan untuk memperoleh besar $\mathrm{j}$ adalah 350. Karena Miksic mengukur index bentuk jaringan dengan formula: $\Pi=j / \varnothing$, maka diperoleh angka index 30 , yang kurang lebih setara dengan jaringan perhubungan di Perancis dewasa ini. Menurut penghitungan yang sebenarnya akan diperoleh index bentuk jaringan :

$-\frac{\mathrm{J}}{\mathrm{j}}=\frac{1.260}{350}=3,6$ 


\section{Jaringan dan Keterpusatan}

Pengukuran pusat suatu jaringan dilakukan melalui penentuan angka tertentu yang disebut dengan angka Konig (konig number). Angka ini menunjukkan jumlah mata rantai terbanyak yang menghubungkan satu titik dengan titik lain dalam suatu jaringan melalui route dan jarak terdekat. Oleh karena itu titik dengan angka Konig terendah merupakan lokasi yang paling efisien di dalam sebuah jaringan dan dianggap sebagai pusat sebuah jaringan. Graf di bawah ini memperlihatkan pengukuran sentralitas berbagai titik suatu jaringan dengan menggunakan angka Konig.

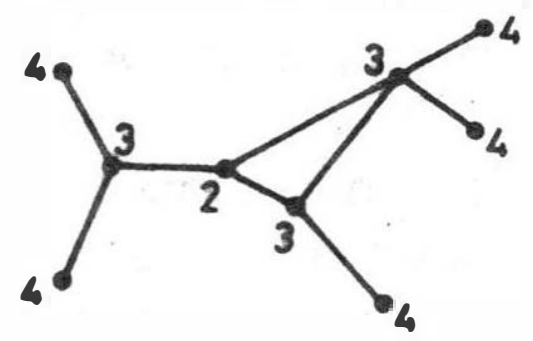

2, 3, dan 4 adalah angka Konig yang dimiliki oleh masing-masing titik.

(Bintarto dan Surastopo, 1982: 97).

Pengukuran keterpusatan suatu jaringan dengan penerapan angka Konig telah pula diterapkan oleh Miksic (1984: 19) di Sumatra Selaian. Angka Konig terendah dimiliki oleh Palembang dan Muaraenim, yang mendukung hipotesis bahwa pusat kerajaan Sriwijaya terletak di sekitar Palembang sekarang. Seyogyanya teknik ini dapat diterapkan pula di kawasan lain, misalnya mengukur keterpusatan Trawulan dalam jaringan perhubungan dan komunikasi abad XIVXV M, di Jawa Tengah dan Timur.

\section{IV}

Bagaimanapun juga harus diakui bahwa distribusi situs atau artefak merupakan salah satu tipe data arkeologi yang penting. Aspek distribusi dengan sendirinya telah menyeret perhatian pengkaji arkeologi pada wujud sistem perilaku dalam kebudayaan, sesuatu yang tidak selalu terjangkau dalam telaah yang membatasi diri pada satuan-satuan situs atau artefak. Walaupun analisis kuantitatif dalam geografi keruangan memberi peluang bagi kajian distribusi di atas, tetapi tulisan sederhana ini tidak sekalipun berpretensi untuk menutup diri dari model hampiran lain. Berbagai hampiran dapat dimanfaat- 
kan guna memahami aspek distribusi dalam arkeologi, termasuk di antaranya subyek tulisan ini, yang kesemuanya dimaksudkan untuk memperluas jangkauan data arkeologi yang terbatas itu.

Salah satu keunggulan hampiran geografi bagi telaah arkeologi adalah karena metoda-metodanya telah teruji pada berbagai studi yang berkaitan erat dengan perilaku manusia dan persebaran hasil budaya manusia masa kini. Sebaliknya sifat kekinian disiplin geografi patut diperhatikan karena jelas tidak memiliki kesejajaran latarbelakang budaya dengan situasi masa lampau. Sehingga pemanfaatannya dalam telaah arkeologi sewajarnyalah memperhatikan persamaan dan perbedaan tersebut. Hampiran dan teknik dalam disiplin geografi yang hampir semuanya lahir di belahan bumi barat pun memperlihatkan berbagai modifikasi pada penerapannya di bumi Indonesia. Dengan kata lain, semakin tinggi intensitas pemanfaatan disiplin geografi dalam telaah arkeologi maka derajad kegunaannya semakin terasa pula seiring dengan berbagai penyesuaian dan modifikasi yang dilakukan terhadapnya.

Berbagai paparan yang tertuang pada halaman-halaman di atas menunjukkan bahwa hampiran geografi keruangan bertalian erat dengan pola perilaku manusia dalam memanfaatkan ruang bagi kegiatannya. Lebih jauh lagi, pola-pola perilaku tersebut dilandasi oleh berbagai gagasan, persepsi, serta sistem nilai tertentu. Kecenderungan yang nampak adalah bahwa pilihan pola-pola tersebut lebih bersifat rasional dan mempertimbangkan pengorbanan yang minim bagi manfaat yang sebesar-besarnya. Walaupun demikian belum atau tidak terdapat petunjuk bahwa aspek non-rasional, misalnya penjajahan, magis, religius, simbolis, dan lain sebagainya, berada pada sisi yang bertolak belakang dengan hampiran geografi keruangan. Pada akhirnya pemilihan metoda yang tepat dalam pemanfaatan teknikteknik tersebut bagi arkeologi Indonesia seyogyanya ditemukan. 


\section{RUUUKAN}

Bambang-Sumadio (ed). 1984. "Jaman Kuna (awal M-1500 M)", Sejarah Nasional Indonesia, II. Jakarta: PN Balai Pustaka.

Bintarto, $R$ dan Surastopo Hadisumarno. 1982. Metode Analisa Geograft. LP3ES.

Budianto, Toha. 1983. "Fenomena Alam Penyebab Runtuhnya Candi Sambisari Kecamatan Kalasan Kabupaten Sleman Yogyakarta", PIA III. Clloto 28 Mei 1983.

Bugie Kusumohartono. 1986. "Perangkat Rekayasa Keairan dan Strategi Penyesuaian Geomorfologi di Kota Majapahit, Trawulan", Kegiatan Ilmiah-Reunidan Ulang Tahun ke-40 FS UGM. Yogyakarta, 22 - 23 Maret 1986.

Clarke, David L. 1977. "Spatial Information in Archaeology", Spatial Archaeology. London: Academic Press. Him. 1 - 32.

Daud Aris Tanudirjo. 1985. "Budaya Sampung sebagai Budaya Transisi Masa Berburu dan Mengumpulkan Makanan Tingkat Lanjut ke Masa Bercocoktanam ", Skripsi Arkeologi FS UGM Yogyakarta.

Foley, Robert. 1977. "Space and Energy: A Method for Analysis Habitat Value and Utilization in Relation to Archaeological Sites", Spatial Archaeology. London: Academic Press. HIm. 163 - 187.

Goenadi Nitihaminoto. 1974. "Laporan Penggalian Prasejarah Gunung Wingko I dan II (belum terbit).

Goenadi Nitihaminoto. 1975. "Laporan Ekskavasi Gunung Wingko III" (belum terbit).

Haggett, P. 1970. "Locational Analysis in Human Geography". London: Edward Arnold.

Haggett, P. 1972. "Geography a Modern Synthesis". London : Harper and Row.

Haris Sukendar. 1971. "Penelitian Megalitik di Daerah Wonosari, Gunung Kidul". Skripsi Arkeologi FSK UGM Yogyakarta.

Harry Widianto. 1985. "Laporan Survei Pojok Tilu, Brebes 1985" (belum terbit). Balai Arkeologi Yogyakarta.

Hasan Djafar. 1978. Girindrawardhana Beberapa Masalah Majapahit Akhir. Ditjen Perguruan Tinggi Departemen Pendidikan dan Kebudayaan. 
Hassan. Fekri. 1981. A Demographic Archaeology. New York: Academic Press.

Heekeren. H.R. van. 1972. "The Stone Age of Indonesia". The Hague Martinus Nijhoff.

Hivemel. F. and I. Hodder. 1984. "Analysis of Artifact Distribution at Ngenyn (Kenya): Depositional and Post Depositional Effects". Intrasite Spatiai Analysis in Archaeology. Cambridge: Cambridge University Press. Hlm. 97 - 115.

Hodder. lan and Olive Orton. 1976. Spatial Analysis in Archaeology. London: Cambridge University Press.

Hodder. Ian. 1977. "Some New Directions in the Spatial Analysis of Archaeological Data at the Regional Scale (Macro)". Spatial Archaeology. London: Academic Press. Him. 223 -349 .

Issatriadi. 1976-1977. Stupika Tanah Liat Bermeterai Gumuk Klinting. Proyek Rehabilitasi dan Perluasan Museum Jawa Timur.

Koentjaraningrat. 1979. Pengantar Ilmu Antropologi. Jakarta: Aksara Baru.

Krom. N.J. 1923. Inleiding tot de Hindoe-Javaansche Kunst. I. 's-Gravenhage: Martinus Nijhoff.

Maulana Ibrahim. 1976. "Kemungkinan Pengetrapan Penelitian Arkeologi di Indonesia dengan Menggunakan Bantuan Foto Udara". Seminar Arkeologi. Cibulan. 2 - 6 Februari 1976.

Meer. N.C. van Setten van der. 1979. Sawah Cultivation in Ancient Java. Canberra: Australia National University Press.

Miksic. J. N. (1984). PENGANALISAAN WILAYAH DAN PERTUMBUHAN KEBUDAYAAN TINGGI DI SUMATRA SELATAN. Berkala Arkeologi. 5(1). 9-24. https://doi.org/10.30883/jba.v5i1.263

Miksic. J. N. 1986. "Pola Permukiman dan Peradaban di Asia Tenggara". Kegiatan llmiah Arkeologi IAAI Komisariat Yogyakarta-Jawa Tengah. Yogyakarta. 16 Mei 1986.

Mundardjiito. 1984. "Pola Pusat Upacara di Situs Muara Jambi'. REEHPA. II. Cisarua. 5 - 10 Maret 1984.

Romondt. van. 1951. Peninggalan-peninggalan Purbakala di Gunung Penanggungan. Dinas Purbakala R.I.

Sampoemo dan Bandono. 1980. "Peranan Geologi dalam Pertumbuhan dan Kehancuran Kerajaan-kerajaan Lama di Jawa dengan Contoh Kerajaan Majapahit". Pertemuan Ilmiah Tahunan IX Ikatan Ahli Geologi Indonesia. Yogyakarta. Desember 1980. 
Selarti Venetsia Saras:vatl dan Bugie Kusumohartono. 1985. "Laporan Kerja Ekskavasi Gumuk Mas I 1985, Candi Deres (Gumuk Candi)" (belum terbit). Balai Arkeologi Yogyakarta.

Simanjuntak, Truman dan Harry Widianto. 1986. "Penelitian Ponjen, Purbalingga, Ja:va Tengah", Laporan Penelitian Arkeologi, 1 (1986). Balai Arkeologi Yogyakarta.

Soejono, R.P. (ed.). 1984. "Jaman Prasejarah di Indonesia", Sejarah Nasional Indonesia, I. Jakarta : PN Balai Pustaka.

Sonny W., Chr. 1984. "Sebaran Situs Kubur sebagai Studi A:vai Pola Pemukiman di Pulau Selayar", REHPA, II. Cisarua, 5 - 10 Maret 1984.

Spaulding, Albert C. 1960. "The Dimensions of Archaeology", Essays in the Science of Cultural in Honor of Leslie A White. Thomas Y. Cro:vch Co. H/m. 437 - 456.

Surastopo Hadisumarno. 1985a. "Manfaat Geomorfologi dan Penginderaan Jauh dalam Kajian Arkeologi", Ceramah pada forum HIMA UGM. Yogyakarta, 17 April 1985.

Surastopo Hadisumarno and Sutikno. 1985b. "Looking for Srivvijaya: A Geomorphological Approach to Locating the Capital of Ancient Kingdom", Regional Symposium Remote Sensing Applications of Socio-Economic of the Environment. Yogyakarta, 4 - 9 Maret 1985.

Surastopo Hadisumamo and Widya Nayati. 1985c. "Archaeological Survey Using Remote Sensing Technique at Plered (The Capital of the Ancient Islamic Mataram Kingdom)", Regional Symposium Remote Sensing Applications of Socio-Economic of the Environment. Yogyakarta, 4 - 9 Maret 1985.

Thomas, David Hurst. 1974. Predicting the Past, An Introduction to Anthropological Archaeology. Ne:v York: Holt, Reinhart and Winston Inc. 